\title{
Physicochemical properties of green hot pepper powders based on drying methods and temperatures
}

\author{
Hyun-Jin Nam, Yong-Jae Lee* \\ Department of Horticultural Bioscience, Pusan National University, Miryang 50463, Korea \\ 건조 방식과 온도에 따른 녹색 고춧가루의 품질 특성 \\ 남현진 · 이용재* \\ 부산대학교 원예생명과학과
}

\begin{abstract}
The optimal drying conditions for fresh green hot peppers (Capsicum annuum. L) were investigated through hypobaric drying (HB) and hot-air drying (HA). $\mathrm{HB}$ was performed at temperature at $35^{\circ} \mathrm{C}, 40^{\circ} \mathrm{C}, 45^{\circ} \mathrm{C}$ and $45^{\circ} \mathrm{C}$ after $80 \%$ dried at $40{ }^{\circ} \mathrm{C}$ and $\mathrm{HA}$ was performed at $40^{\circ} \mathrm{C}, 50^{\circ} \mathrm{C}, 60^{\circ} \mathrm{C}$ and $50^{\circ} \mathrm{C}$ after $80 \%$ dried at $50{ }^{\circ} \mathrm{C}$. $\mathrm{HB}$ offered a lower drying temperature and reduced drying time. The quality of the vivid green color of the dried power was superior for peppers dried at 35 and $40^{\circ} \mathrm{C}$ through $\mathrm{HB}$ and at $40^{\circ} \mathrm{C}$ and $50^{\circ} \mathrm{C}$ via $\mathrm{HA}$ to others. Considering the drying time, $40^{\circ} \mathrm{C} \mathrm{HB}(42 \mathrm{~h})$ and $50^{\circ} \mathrm{C} \mathrm{HA}(23 \mathrm{~h})$ were ideal compared to the other six treatments. Through both drying methods, the flesh and seeds of the peppers exhibited more significant brown discoloration with increasing temperature. Epidermis whitening, which is the discoloration of green hot peppers during drying, occurred at a higher rate at lower temperatures, resulting in a lighter green pepper powder through $35^{\circ} \mathrm{C} \mathrm{HB}$ and $40^{\circ} \mathrm{C} \mathrm{HA}$. The water absorption index increased as the temperature lowered, but the water solubility index did not change. The capsiacinoids concentration did not vary between the powders undergoing $40^{\circ} \mathrm{C} \mathrm{HB}$ and $50^{\circ} \mathrm{C} \mathrm{HA}$; however, the vitamin $\mathrm{C}$ concentration was higher in the powder subjected to $40^{\circ} \mathrm{C} \mathrm{HB}$.
\end{abstract}

Key words : green hot pepper, hypobaric drying, hot-air drying, pepper powder, quality characteristics

\begin{abstract}
서 론
고추(Capsicum annum. L)는 가지과에 속하는 남아메리 카가 원산의 작물로 우리나라에는 약 400년 전에 도입되었 다(Joo 등, 1995). 현재 국내 조미채소 면적의 약 $47 \%$ 를 차지하는 주요 작물이며, 국민 1 인당 연간 $4.1 \mathrm{~kg}$ 의 건고추 를 소비하고 있다(Hong, 1999). 고추는 매운맛이 가장 중요 한 특성으로 capsaicin이 주성분이며, 품종에 따라 매운맛 의 정도가 다르고 vitamin $\mathrm{C}$ 와 $\mathrm{E}$ 및 $\mathrm{A}$ 가 풍부하다(Siddiqui,
\end{abstract} 2015).
고춧가루는 전통적으로 홍고추를 건조하여 제조하기 때문에 매운맛을 내기 위해 고춧가루를 첨가하면 식품 전체가 붉은색을 띄게 된다. 하지만 근래에는 식생활과 식품에 대한 기호가 다양해지면서 붉은색을 띄지 않으면 서 매운맛을 낼 수 있는 식재료에 대한 필요가 생겨나고 있다(Shin과 Choi, 2011). 또한, 풋고추는 생과 상태로 저장 이 어려워 수급조절과 가격안정, 보관과 사용의 편리성, 새로운 수요의 창출을 위해서도 건조를 통한 녹색 고춧가 루의 개발이 요구되고 있다.

고추를 건조하는 방법으로는 천일건조와 열풍건조 방

*Corresponding author. E-mail : yjl@pusan.ac.kr, Phone : +82-55-350-5524, Fax : +82-55-350-5529

Received 17 January 2020; Revised 07 February 2020; Accepted 07 February 2020.

Copyright (c) The Korean Society of Food Preservation.

This is an Open Access article distributed under the terms of the Creative Commons Attribution Non-Commercial License (http://creativecommons.org/licenses/by-nc/4.0) which permits unrestricted non-commercial use, distribution, and reproduction in any medium, provided the original work is properly cited. 
법이 많이 사용되고 있다. 천일건조는 태양열을 이용해 건조하는 방법으로 건조온도가 높지 않아 색, 영양성분의 파괴 등 품질 변화는 적지만 건조기간이 7일 이상 소요되 고 기후의 영향을 많이 받아 효율이 좋지 못하며 건조 중 위생상의 문제가 발생하기도 한다(Yang, 2008).

열풍건조는 건조 시간이 짧고 농가에서 간편하게 이용 할 수 있는 장점이 있으나 높은 열에 의해 고추의 색이 검붉게 변하고 영양성분이 파괴되는 단점이 있다. 이러한 문제로 인해 천일건조와 열풍건조의 단점을 보완할 수 있는 원적외선 건조 등의 다양한 건조방법들이 보고되고 있다(Joo 등, 1995; Park 등, 2003; Jeong 등, 2007).

송풍형 감압건조는 비교적 최근에 일부 농산물에 활용 되고 있는데, 저압과 송풍을 동시에 행하는 방식으로 대기 압보다 낮은 압력에서 수분이 쉽게 증발되는 현상을 이용 한 건조방법이다. 열풍건조보다는 낮은 온도에서 건조가 가능하고 동결진공건조보다는 품질은 낮으나 비용이 적 게 들고 건조 효율이 높은 장점을 지니고 있다. 높은 온도 에서 건조 시 변색이 심한 풋고추 건조에 기대되는 건조방 법 중 하나로 판단된다.

따라서 본 연구는 농가에서 쉽게 사용할 수 있는 열풍건 조와 풋고추 건조에 효과적일 것으로 기대되는 송풍형 감압건조를 활용하여 풋고추 건조에 적합한 건조조건을 구명하고자 하였다.

\section{재료 및 방법}

\section{실험재료}

‘청양' 품종 (C. annuum L cv. Cheongyang)을 본 실험에 사용하였다. 수확 다음날 현지 선별장에서 구매하여 실험 실로 옮겼다. 미숙과와 과숙과를 제거하고 세척한 후 물기 를 제거하여 사용하였다.

\section{건조조건}

고추는 $3 \mathrm{~cm}$ 크기로 절단하여 송풍형 감압건조기 (KJ-D0311M, Kyung Jin Air System Co. Ltd, Daegu, Korea) 를 이용하여 $640 \mathrm{mmHg}$ 에서 $35^{\circ} \mathrm{C}, 40^{\circ} \mathrm{C}, 45^{\circ} \mathrm{C}$ 를 건조 완료 시까지 그대로 유지하는 처리와 $40^{\circ} \mathrm{C}$ 에서 $80 \%$ 이상 건조 후 $45^{\circ} \mathrm{C}$ 에서 건조 $\left(40 / 45^{\circ} \mathrm{C}\right)$ 하는 처리를 두었으며, 열풍건 조기(LMD-600R, Dae Young E\&B, Ansan, Korea)를 사용 하여 $40^{\circ} \mathrm{C}, 50^{\circ} \mathrm{C}, 60^{\circ} \mathrm{C}$ 를 건조 완료시까지 그대로 유지하 는 처리와 $50^{\circ} \mathrm{C}$ 에서 $80 \%$ 이상 건조 후 $60^{\circ} \mathrm{C}$ 에서 건조 $\left(50 / 60{ }^{\circ} \mathrm{C}\right)$ 하는 처리를 두었다. 건조는 최종수분함량이 13 - $14 \%$ 가 될 때 종료하였다. 건조된 고추는 분쇄기(SMXH4545 WS, ShinIl Industrial Co. Ltd., Seoul, Korea)로 30초 간 분쇄하여 $40 \mathrm{mesh}$ 의 채로 쳐서 $280-500 \mu \mathrm{m}$ 크기의 고춧가루를 품질평가에 사용하였다.

\section{품질 특성 측정}

\section{변색}

건조한 고추의 변색은 육안으로 관찰하여 지수값으로 수치화하였다. 종자변색은 갈변정도에 따라 4등급으로 판 단하였다(Seed browning index: 0=whitish yellow, 1=brown, $2=$ dark brown, $3=$ black). 과육갈변도 변색정도에 따라 4등 급으로 판단하였다(Flesh browning index: $0=$ green, $1=$ dark green, $2=51-80 \%$ browning, $3=81-100 \%$ browning). 그리 고 표피백화도 백화정도에 따라 4등급으로 판단하였다 (Epidermis whitening index: $0=$ green, $1=5-10 \%$ whitening, $2=11-50 \%$ whitening, $3=51-100 \%$ whitening).

\section{색도}

고춧가루 $5 \mathrm{~g}$ 을 $10 \times 10 \mathrm{~cm}$ 두께의 $40 \mu \mathrm{m}$ oriented polypropylene(OPP) 필름에 담아 색차계(Minolta Camera Co., Ltd., Model No. CR-200, Osaka, Japan)를 사용하여 Hunter $\mathrm{L}, \mathrm{a}, \mathrm{b}$ 값을 측정하였다.

\section{$\mathrm{pH}$}

고춧가루 $1 \mathrm{~g}$ 을 증류수 $20 \mathrm{~mL}$ 에 혼합하여 $25^{\circ} \mathrm{C}$ 항온수 조에서 1시간 동안 교반하여 원심분리 후 $\mathrm{pH}$ meter (SevenGo SG2, Mettler Toledo, Seven go ${ }^{\mathrm{TM}}$, Schwerzenbach, Switzerland)로 측정하였다.

\section{Total chlorophyll}

고춧가루 $2 \mathrm{~g}$ 을 $85 \%$ acetone $20 \mathrm{~mL}$ 에 넣고 암실에서 24시간 추출하여, $642.5 \mathrm{~nm}$ 와 $660 \mathrm{~nm}$ 에서 spectrophotometer(Model No. Optizen 3220UV BIO, Mecasys Co. Ltd, Daejeon, Korea)로 측정한 후 다음 식으로 환산하여 정량하 였다.

Total chlorophyll $=7.12 \mathrm{~A}_{660.0}+16.8 \mathrm{~A}_{642.5}$

\section{수분흡수지수(WAI) 및 수분용해지수(WSI)}

건조방법을 달리한 고춧가루의 수분흡수지수(water absorption index, WAI) 값과 수분용해지수(water solubility index, WSI)값의 측정은 고춧가루 $1 \mathrm{~g}$ 을 증류수 $20 \mathrm{~mL}$ 와 혼합하여 $25^{\circ} \mathrm{C}$ 항온수조에서 $120 \mathrm{rpm}$ 의 속도로 1 시간 교반 후 원심분리 $\left(12,000 \mathrm{rpm}, 20 \mathrm{~min}, 4^{\circ} \mathrm{C}\right)$ 하였다. 고형분량은 원심분리한 시료의 상등액을 $105^{\circ} \mathrm{C}$ 에서 12 시간 건조한 무 게를 측정하였고, 침전물의 양은 건조하지 않고 무게를 측 정하여 아래의 식을 이용하여 WAI와 WSI 값을 구하였다.

$$
\text { 수분흡수지수 }(\mathrm{WAI})=\text { 침전물의 양/시료량 }
$$


수분용해지수 $(\mathrm{WSI})=$ 상등액의 고형분량/시료량 $\times 100$

\section{Capsaicinoids 및 vitamin C}

Capsaicinoid는 Namgung 등(2013)의 방법에 따라 분석 하였으며, vitamin $\mathrm{C}$ 는 식품공전 비타민류 시험법에 따라 고춧가루 $2 \mathrm{~g}$ 을 $5 \%$ meta phosphoric acid로 추출하여 분석 하였다.

\section{통계 분석}

각 처리는 $2 \mathrm{~kg}$ 씩 3 반복 하였다. 실험결과의 분석은 SPSS 통계프로그램(Statistical Package for the Social Science, Ver. 23 SPSS Inc., Chicago, USA)을 이용하여 구하였다. 요인분 석은 t-test와 one-way ANOVA(Analysis of variation)를 이 용하였고, 처리에 의한 평균값의 차이는 Duncan's multiple range test를 이용하여 $p<0.05$ 수준에서 검정하였다.

\section{결과 및 고찰}

\section{건고추 변색 및 고춧가루 chlorophyll, $\mathrm{pH}$ 및 색도}

감압건조가 열 풍건조보다 낮은 온도에서도 건조가 가 능하였으며, 건조시간이 단축되는 효과가 있었다. $40^{\circ} \mathrm{C}$ 의 동일한 온도조건에서 비교해 보면 감압건조가 11시간 정 도 빨랐으나 두 방식에서 각각 변색이 적게 발생되어 외관 적 품질이 우수하게 나타난 감압건조 $40^{\circ} \mathrm{C}$ 와 열풍건조 $50^{\circ} \mathrm{C}$ 를 비교하면 열풍건조가 8 시간 정도 빨랐다(Table 1). 변색은 건고추의 색 품질에 중요한 요인으로 작용하는 데, 정도의 차이는 있으나 두 방식 모두에서 종자갈변(seed browning)과 과육갈변(flesh browning) 그리고 표피백화 (epidermis whitening) 현상이 발생되었다(Fig. 1). 종자갈변 은 열 풍건조보다 건조시간이 긴 감압건조에서 높았으며, 각 건조방식에서는 온도가 높을수록 증가하는 경향을 보 였다(Table 1). 또한, 두 방식 모두에서 각각 $80 \%$ 건조 후 $45^{\circ} \mathrm{C}$ 와 $60^{\circ} \mathrm{C}$ 로 승온한 처리가 단일 건조온도처리보다 종 자갈변이 많이 감소하는 특이한 현상을 보였다. 이는 종자 갈변에 건조온도와 시간이 복합적으로 작용하며 특히, 건 조가 많이 진행된 건조후기의 건조속도가 종자갈변에 다 소 큰 영향을 미치는 것으로 판단되었다. 과육갈변은 감압 건조보다 열풍건조에서 더 많이 발생되었으며, 온도가 높 을수록 증가하는 경향을 보였다(Table 1). 온도가 낮은 감 압건조 $35^{\circ} \mathrm{C}$ 와 열풍건조 $40^{\circ} \mathrm{C}$ 에서는 전혀 발생되지 않았 으며, 감압건조는 $45^{\circ} \mathrm{C}$ 에서 1.78 로 가장 높았고, 열풍건조 는 $60^{\circ} \mathrm{C}$ 에서 2.52 로 가장 높았다. 풋고추의 과육변색에 영향을 미치는 대표적인 색소는 chlorophyll인데, 대체로 chlorophyll a가 b보다 쉽게 변색된다(Lee 등, 2006; Cho 등, 2011). Chlorophyll은 porphyrin ring 내에 있는 $\mathrm{Mg}$ 이 이탈되면 변색되는데 효소, 산, 알칼리, 금속, 온도, 빛 등이 복합적으로 작용하는 것으로 알려져 있다(Buckle와 Edwards, 1970; Robertson, 1985; Yamauchi와 Watada, 1991;

Table 1. Seed browning, flesh browning and epidermis whitening of dried green hot pepper and drying time according to drying methods combined with temperatures

\begin{tabular}{|c|c|c|c|c|c|}
\hline $\begin{array}{l}\text { Drying } \\
\text { method }\end{array}$ & $\underset{\left({ }^{\circ} \mathrm{C}\right)}{\text { Temp. }}$ & $\begin{array}{l}\text { Drying time } \\
\text { (h) }\end{array}$ & $\begin{array}{l}\text { Seed browning } \\
\text { index }^{1)}\end{array}$ & $\begin{array}{l}\text { Flesh browning } \\
\text { index }\end{array}$ & $\begin{array}{l}\text { Epidermis whitening } \\
\text { index }^{3)}\end{array}$ \\
\hline \multirow{4}{*}{$\begin{array}{l}\text { Hypobaric } \\
\text { drying }\end{array}$} & 35 & 48 & $0.87 \pm 0.09^{\mathrm{b} 6)}$ & $0.00 \pm 0.00^{\mathrm{f}}$ & $2.89 \pm 0.07^{\mathrm{a}}$ \\
\hline & 40 & 31 & $0.93 \pm 0.06^{\mathrm{b}}$ & $0.85 \pm 0.04^{\mathrm{d}}$ & $1.36 \pm 0.17^{\mathrm{c}}$ \\
\hline & 45 & 26 & $1.20 \pm 0.04^{\mathrm{a}}$ & $1.78 \pm 0.09^{b}$ & $0.37 \pm 0.09^{d}$ \\
\hline & $40 / 45^{4)}$ & 27 & $0.44 \pm 0.07^{\mathrm{c}}$ & $0.63 \pm 0.06^{\mathrm{e}}$ & $1.89 \pm 0.19^{\mathrm{b}}$ \\
\hline \multirow{4}{*}{$\begin{array}{l}\text { Hot-air } \\
\text { drying }\end{array}$} & 40 & 42 & $0.62 \pm 0.06^{\mathrm{c}}$ & $0.00 \pm 0.00^{\mathrm{f}}$ & $3.00 \pm 0.00^{\mathrm{a}}$ \\
\hline & 50 & 23 & $0.62 \pm 0.04^{\mathrm{c}}$ & $1.00 \pm 0.02^{\mathrm{d}}$ & $1.17 \pm 0.13^{\mathrm{c}}$ \\
\hline & 60 & 15 & $0.83 \pm 0.05^{\mathrm{b}}$ & $2.52 \pm 0.01^{\mathrm{a}}$ & $0.41 \pm 0.02^{\mathrm{d}}$ \\
\hline & $50 / 60^{5)}$ & 16 & $0.49 \pm 0.01^{\mathrm{c}}$ & $1.24 \pm 0.09^{\mathrm{c}}$ & $1.15 \pm 0.05^{\mathrm{c}}$ \\
\hline \multicolumn{2}{|c|}{ Significance } & - & *** & $* * *$ & **** \\
\hline
\end{tabular}

\footnotetext{
${ }^{1)}$ Seed browning index: $0=$ whitish yellow, $1=$ brown, $2=$ dark brown, $3=$ black.

${ }^{2)}$ Flesh browning index: $0=$ green, $1=$ dark green, $2=51-80 \%$ browning, $3=81-100 \%$ browning.

${ }^{3)}$ Epidermis whitening index: $0=$ green, $1=5-10 \%$ whitening, $2=11-50 \%$ whitening, $3=51-100 \%$ whitening

4) After dry until $80 \%$ weight loss at $40^{\circ} \mathrm{C}$ and then dry at $45^{\circ} \mathrm{C}$.

${ }^{5)}$ After dry until $80 \%$ weight loss at $50^{\circ} \mathrm{C}$ and then dry at $60^{\circ} \mathrm{C}$.

${ }^{6}$ Mean \pm SE $(n=3)$ separation within columns by Duncan's multiple range test at $\mathrm{p}<0.05$.

${ }^{* *}$ Significant at $\mathrm{p}<0.001$, respectively.
} 

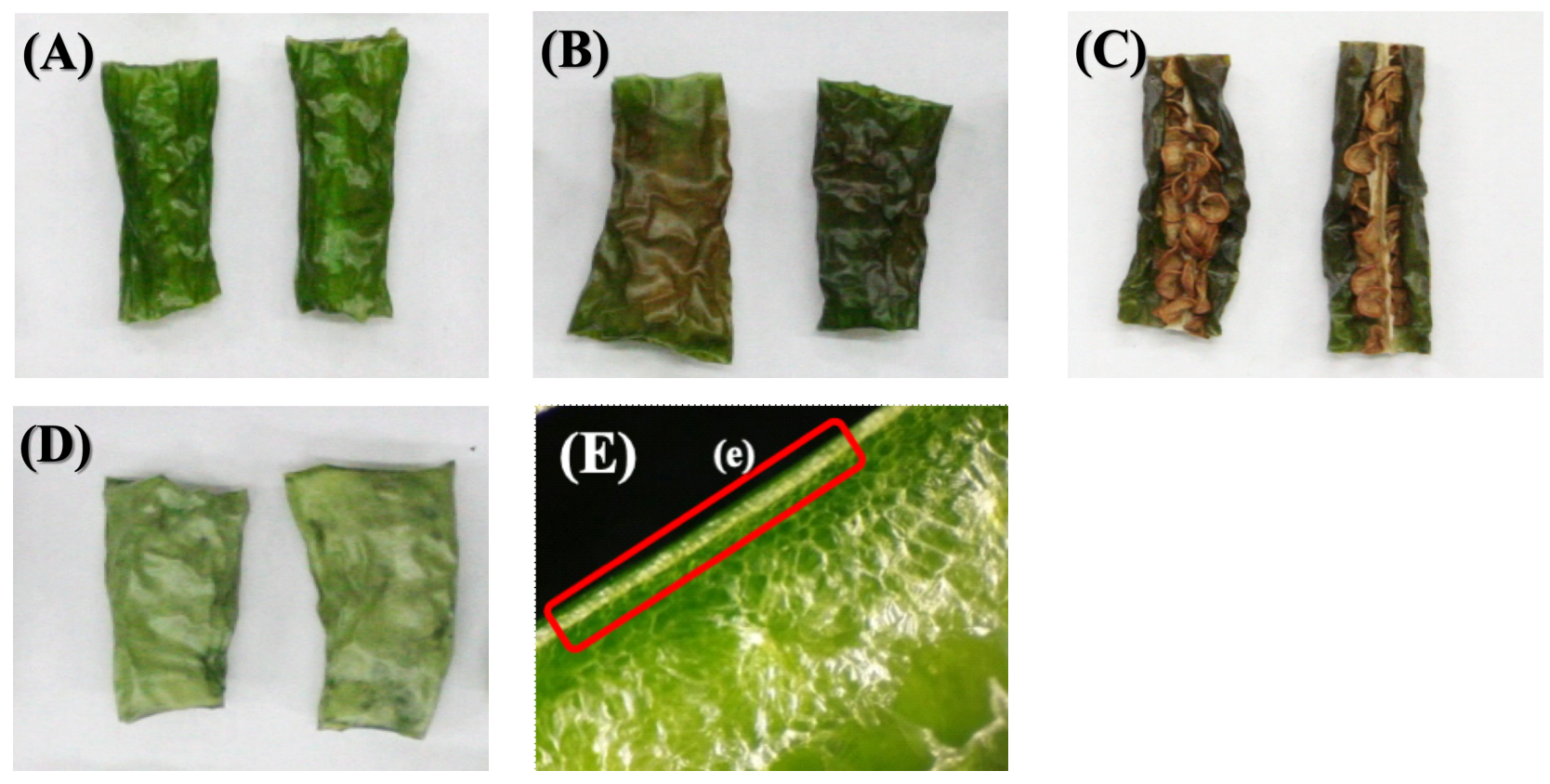

Fig. 1. Types of discoloration of dried green hot pepper.

Normal (A), flesh browning (B), seed browning (C) epidermis whitening (D), cross section of epidermis whitening (E) and whitened epidermal tissue (e).

Butx 등, 2002; Schoefs, 2002; Kwak과 Kim, 2009). 고춧가루 의 chlorophyll 함량과 $\mathrm{pH}$ 를 조사한 결과를 보면(Fig. 2), 건조온도가 높을수록 $\mathrm{pH}$ 는 낮게 나타났으며 chlorophyll 함량도 낮았다. 이는 porphyrin ring 내에 있는 $\mathrm{Mg}^{2+}$ 가 $\mathrm{H}^{+}$로 치환되어 pheophytin으로 전환된 것에 기인된 것으로 생각 된다. 채소 건조에 대한 다른 연구에서도 온도가 높을수록, 그리고 $\mathrm{pH}$ 가 낮을수록 chlorophyll 함량이 감소한다고 하 였다(Choe 등, 2001; $\mathrm{Ku}$ 등, 2006; Beom 등, 2007; Kwak과 Kim, 2009).

표피백화는 풋고추 건조에서 나타나는 특이한 현상으 로 이해되는데, 과피의 표피(epidermis) 조직이 다소 투명 한 느낌을 띄면서 희게 보이는 증상이다(Fig. 1D). 이와 같은 증상은 건조 후반에 많이 나타나는 과육갈변과 달리 건조 초기에 많이 나타났는데, 건조방식에 관계없이 가장 낮은 온도에서 건조했을 때 많이 나타나고 건조온도가 높을 수록 적게 발생되었다. 또한 낮은 온도에서 $80 \%$ 건조 후 승온하여 건조를 완료한 처리 (감압 $40 / 45^{\circ} \mathrm{C}$, 열풍 $50 / 60^{\circ} \mathrm{C}$ ) 에서도 건조 초기온도가 같은 처리 (감압 $40^{\circ} \mathrm{C}$, 열풍 $50^{\circ} \mathrm{C}$ ) 와 비슷한 결과를 보여, 건조 초기 수분이 많은 과실을 낮은 온도에서 장시간 건조함에 따라 갈변과는 다른 화학 적, 물리적 변화가 발생되는 것으로 사료되었다. 표피백화 가 발생된 건조고추의 단면을 살펴보면(Fig. 1E), 바깥쪽에 얇은 흰색 층이 생기며 층의 안쪽은 녹색이 그대로 유지되 고 있었다. Chlorophyll 함량 조사 결과(Fig. 2A), 표피백화
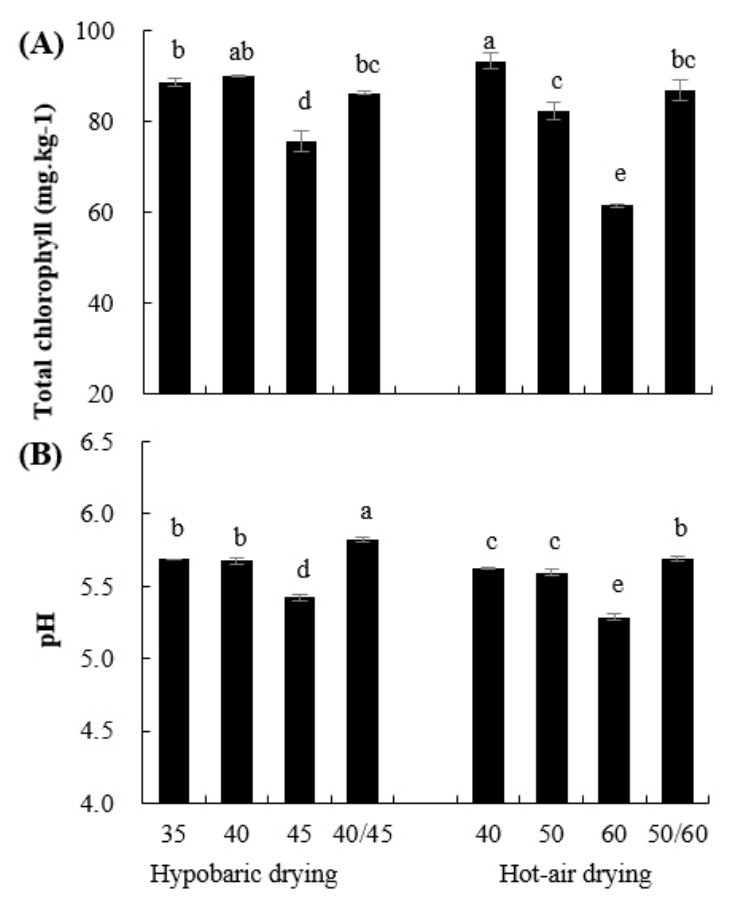

Drying method and temperature $\left({ }^{\circ} \mathrm{C}\right)$

Fig. 2. Total chlorophyll (A) and pH (B) of green hot pepper powder according to drying methods combined with temperatures. $40 / 45$ means drying until $80 \%$ weight loss at $40^{\circ} \mathrm{C}$ and then drying at $45^{\circ} \mathrm{C}$. $50 / 60$ means drying until $80 \%$ weight loss at $50^{\circ} \mathrm{C}$ and then drying at $60^{\circ} \mathrm{C}$. Small alphabetic letters on the figure indicate mean separation significance at $\mathrm{p}<0.05$ by Duncan's multiple range test. Bars indicate standard error $(\mathrm{n}=3)$. 
현상이 가장 많이 발생된 열풍 $40^{\circ} \mathrm{C}$ 에서 chlorophyll 함량 이 가장 높은 것으로 보아, 과육조직의 chlorophyll까지 파 괴된 것은 아닌 것으로 판단되었다. 이와 같은 표피백화는 홍고추 건조 시 나타나는 희나리와 외관적으로는 다소 비슷해 보이지만, 곰팡이의 감염이나 천일건조 시 습한 환경에서 햇빛에 의한 손상을 막기 위해 카로티노이드 색소가 항산화제로 작용하면서 발생하는 희나리 현상과 는 매우 다른 것으로 판단되었다(Lee, 2003; Lee 등, 2006). 표피백화는 과육갈변과 달리 분쇄하여 고춧가루를 만들 어 육안으로 관찰하였을 때 다소 밝은 녹색을 띄며 건조방 법에 따라 각각 우수한 품질을 나타낸 감압건조 $40^{\circ} \mathrm{C}$, 열풍 건조 $50^{\circ} \mathrm{C}$ 와 큰 차이를 나타내지 않았다(Fig. 3).

고춧가루의 색도를 측정한 Hunter $\mathrm{L}, \mathrm{a}, \mathrm{b}$ 값은 두 건조방 식 간에는 큰 차이가 없었으나 온도와는 매우 유의적인 차이를 나타내었다(Table 2). 색의 밝기를 나타내는 Hunter $\mathrm{L}$ 값은 온도가 낮을수록 높았고, 녹색의 정도를 나타내는 Hunter a 값도 온도가 낮을수록 녹색이 강하였다. 그러나 육안으로 관찰되는 녹색의 강도는 감압건조의 경우 $35^{\circ} \mathrm{C}$ 보다 $40^{\circ} \mathrm{C}$ 에서, 열풍건조의 경우 $40^{\circ} \mathrm{C}$ 보다 $50^{\circ} \mathrm{C}$ 에서 더 높게 관찰되었는데, 이는 낮은 온도에서 많이 발생한 표피 백화 현상이 영향을 미친 것으로 판단된다(Fig. 3). 감압건 조 $45^{\circ} \mathrm{C}$ 와 열풍건조 $60^{\circ} \mathrm{C}$ 는 변색이 심하였다. 육안으로 관찰되는 상품성은 감압건조 $35^{\circ} \mathrm{C}$ 와 열풍건조 $40^{\circ} \mathrm{C}$ 가 비 슷하였고, 감압건조 $40^{\circ} \mathrm{C}$ 와 열풍건조 $50^{\circ} \mathrm{C}$ 가 비슷하였다. 상기 네 종류에 대한 선호도는 개인마다 상이하였는데,
고춧가루는 일반적으로 조리용으로 사용되므로 조리하였 을 때의 색, 맛, 그리고 물리적 특성 등을 고려한 관능평가 가 필요할 것으로 판단되었다.

\section{고춧가루 WAI 및 WSI}

건조방식과 온도에 따른 수분흡수지수(WAI)는 건조방 식에 관계없이 건조온도가 낮을수록 높았으며 수분용해 지수(WSI)는 유의적인 차이를 보이지 않았다(Fig. 4). 건조 중에는 열에 의해 조직 손상이 발생하고, 가용성 고형물질 이 수분과 함께 이동하는 현상이 발생하고, 수축하여 복원 성을 잃거나 표면 경화현상 등의 물리적인 변화가 일어난 다고 보고되고 있다(Pyun 등, 2014). 각종 채소류를 건조한 후 수분흡수능력을 조사한 보고에 따르면 낮은 온도에서 건조한 채소가 열에 의한 손상을 덜 받기 때문에 수분흡수 능력이 높으며, 복원 후 품질이 높은 것으로 평가를 받고 있다(Hwang과 Rhim, 1994). 본 실험에서도 감압건조 $35^{\circ} \mathrm{C}$ 의 수분흡수능력이 $4.95 \mathrm{~g} \cdot \mathrm{g}^{-1}$ 로 가장 높았으며 열풍건조 $60^{\circ} \mathrm{C}$ 가 $3.49 \mathrm{~g} \cdot \mathrm{g}^{-1}$ 로 가장 낮게 나타났다. 낮은 온도에서 $80 \%$ 건조 후 승온하여 건조를 완료한 감압건조 $40 / 45^{\circ} \mathrm{C}$ 와 열풍건조 $50 / 60^{\circ} \mathrm{C}$ 의 수분흡수지수는 감압건조 $40^{\circ} \mathrm{C}, 45^{\circ} \mathrm{C}$, 열풍건조 $50^{\circ} \mathrm{C}$ 와 비슷하여 건조 초기의 온도가 수분흡수 지수에 영향을 미치는 것으로 판단되었다. 수분용해지수 는 감압건조 $40^{\circ} \mathrm{C}$ 가 $7.21 \%$ 로 가장 낮았고, 열풍건조 $50 / 60^{\circ} \mathrm{C}$ 가 $10.43 \%$ 로 높았으며, 그 외의 건조구는 건조방식과 온도 에 따른 차이가 없었다.
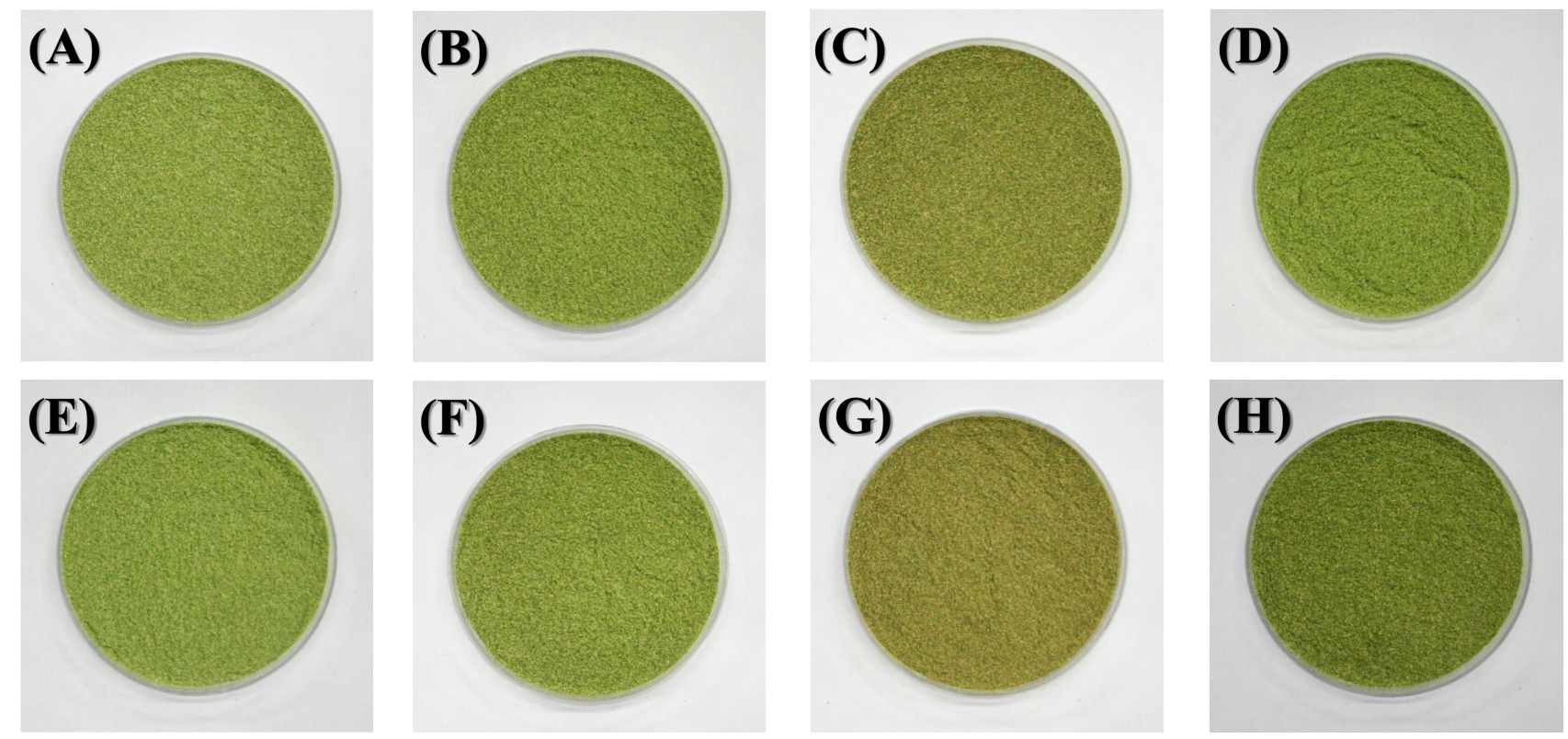

Fig. 3. Comparison of green hot pepper powder according to drying methods combined with temperatures.

$35^{\circ} \mathrm{C}$ hypobaric drying (A), $40^{\circ} \mathrm{C}$ hypobaric drying (B), $45^{\circ} \mathrm{C}$ hypobaric drying (C), hypobaric drying until $80 \%$ weight loss at $40{ }^{\circ} \mathrm{C}$ and then at $45^{\circ} \mathrm{C}$ (D), $40^{\circ} \mathrm{C}$ hot-air drying (E), $50^{\circ} \mathrm{C}$ hot-air drying $(\mathrm{F}), 60^{\circ} \mathrm{C}$ hot-air drying $(\mathrm{G})$, hot-air drying until $80 \%$ weight loss at $50{ }^{\circ} \mathrm{C}$ and then at $60^{\circ} \mathrm{C}(\mathrm{H})$. 
Table 2. Hunter $\mathbf{L}$, a and $b$ of green hot pepper powder according to drying methods combined with temperatures

\begin{tabular}{|c|c|c|c|c|}
\hline \multirow{2}{*}{ Drying method } & \multirow{2}{*}{$\begin{array}{c}\text { Temp. } \\
\left({ }^{\circ} \mathrm{C}\right)\end{array}$} & \multicolumn{3}{|c|}{ Hunter } \\
\hline & & $\mathrm{L}$ & $\mathrm{a}$ & $\mathrm{b}$ \\
\hline \multirow{4}{*}{ Hypobaric drying } & 35 & $66.17 \pm 0.30^{\mathrm{b} 3)}$ & $-8.73 \pm 0.17^{\mathrm{ab}}$ & $23.42 \pm 0.18^{\mathrm{a}}$ \\
\hline & 40 & $64.43 \pm 0.17^{\mathrm{c}}$ & $-8.42 \pm 0.10^{\mathrm{b}}$ & $23.53 \pm 0.20^{\mathrm{a}}$ \\
\hline & 45 & $60.72 \pm 0.24^{\mathrm{f}}$ & $-5.17 \pm 0.24^{\mathrm{e}}$ & $21.11 \pm 0.18^{d}$ \\
\hline & $40 / 45^{1)}$ & $65.62 \pm 0.57^{\mathrm{b}}$ & $-8.45 \pm 0.21^{\mathrm{b}}$ & $22.81 \pm 0.19^{b}$ \\
\hline \multirow{4}{*}{ Hot-air drying } & 40 & $67.12 \pm 0.36^{\mathrm{a}}$ & $-9.16 \pm 0.08^{\mathrm{a}}$ & $23.34 \pm 0.09^{\mathrm{ab}}$ \\
\hline & 50 & $63.25 \pm 0.23^{\mathrm{d}}$ & $-7.72 \pm 0.13^{\mathrm{c}}$ & $23.38 \pm 0.34^{\mathrm{ab}}$ \\
\hline & 60 & $61.73 \pm 0.26^{\mathrm{e}}$ & $-3.93 \pm 0.08^{\mathrm{f}}$ & $22.01 \pm 0.13^{\mathrm{c}}$ \\
\hline & $50 / 60^{2)}$ & $63.24 \pm 0.20^{\mathrm{d}}$ & $-6.97 \pm 0.03^{\mathrm{d}}$ & $22.06 \pm 0.01^{\mathrm{c}}$ \\
\hline \multicolumn{2}{|c|}{ Significance } & *** & $* * *$ & *** \\
\hline
\end{tabular}

${ }^{1)}$ After dry until $80 \%$ weight loss at $40^{\circ} \mathrm{C}$ and then dry at $45^{\circ} \mathrm{C}$.

${ }^{2}$ After dry until $80 \%$ weight loss at $50^{\circ} \mathrm{C}$ and then dry at $60^{\circ} \mathrm{C}$.

${ }^{3)} \mathrm{Mean} \pm \mathrm{SE}(\mathrm{n}=3)$ separation within columns by Duncan's multiple range test at $\mathrm{p}<0.05$.

${ }^{* * *}$ Significant at $\mathrm{p}<0.001$, respectively.
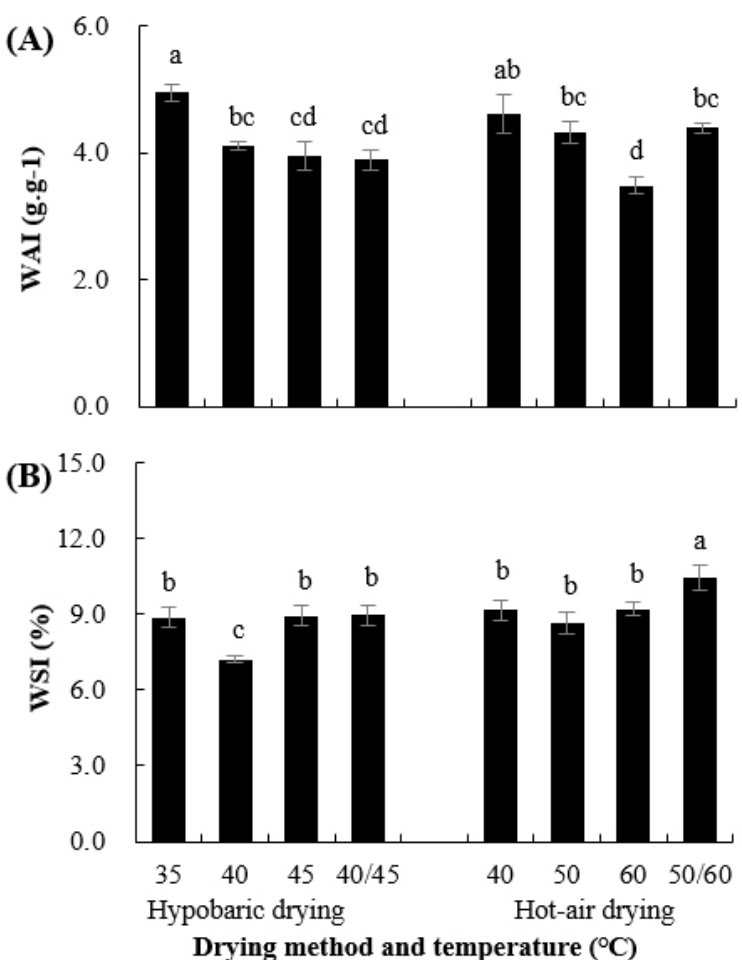

Fig. 4. WAI (A) and WSI (B) values of green hot pepper powder according to drying methods combined with temperatures.

WAI, water absorption index; WSI, water solubility index. 40/45 means drying until $80 \%$ weight loss at $40^{\circ} \mathrm{C}$ and then drying at $45^{\circ} \mathrm{C} .50 / 60$ means drying until $80 \%$ weight loss at $50^{\circ} \mathrm{C}$ and then drying at $60^{\circ} \mathrm{C}$. Small alphabetic letters on the figure indicate mean separation significance at $\mathrm{p}<0.05$ by Duncan's multiple range test. Bars indicate standard error $(\mathrm{n}=3)$.

\section{Capsaicinoids 및 vitamin C}

Capsaicinoid는 고추의 매운맛을 나타내는 성분으로 capsaicin, dihydrocapsaicin, nordi hydrocapsaicin, homocapsaicin, homodihydrocapsaicin 등이 있으며 capsaicin과 dihydrocapsaicin이 $90 \%$ 정도를 차지하는데 조성과 비율에 따라 매운맛의 정도가 다르다고 보고되고 있다(Attuquayefio 와 Buckle, 1987; Namgung 등, 2013). 외관상 가장 우수한 품질을 나타내었던 감압건조 $40^{\circ} \mathrm{C}$ 와 열풍건조 $50^{\circ} \mathrm{C}$ 의 capsaicinoid와 vitamin $\mathrm{C}$ 의 함량은 Table 3 과 같다. 홍고추 의 선행 연구결과에 따르면 건조온도에 따른 capsaicinoid 의 함량은 유의적인 차이를 나타내지 않는다고 보고하였 는데(Daood 등, 2006; Lim 등, 2012), 본 풋고추 실험에서도 열 풍건조 $50^{\circ} \mathrm{C}$ 의 capsaicin과 dihydrocapsaicin 함량이 다소 높았으나 유의적인 차이는 없었다. Vitamin C는 열, 산소, 빛에 영향을 많이 받아 고춧가루를 비롯한 여러 건조 농산 물의 품질을 평가하는 중요한 지표(Lin 등, 1998; Fellows, 2009; $\operatorname{Lim}$ 등, 2012)로 선행 연구 결과에 따르면 건조방법 에 상관없이 건조온도가 높고 건조 시간이 길수록 vitamin $\mathrm{C}$ 의 파괴가 많은 것으로 보고하였다(Jin 등, 2006; $\mathrm{Lim}$ 등, 2012; Park 등, 2014). 본 실험에서는 건조시간이 길고 건조온도가 낮은 감압건조 $40^{\circ} \mathrm{C}$ 의 vitamin $\mathrm{C}$ 함량이 209.97 $\mathrm{mg} \cdot 100 \mathrm{~g}^{-1}$ 으로 열풍건조 $50^{\circ} \mathrm{C}$ 의 $149.87 \mathrm{mg} \cdot 100 \mathrm{~g}^{-1}$ 보다 유의적으로 낮아 건조시간보다 온도에 더 영향을 받는 것으로 나타났다.

이상의 결과를 종합해 볼 때, 송풍형 감압건조는 열풍건 조보다 낮은 온도에서 건조가 가능했으며, 건조시간을 단 축시킬 수 있었다. 건조 중 발생되는 종자변색, 과육갈변, 
Table 3. Capsaicinoid and vitamin $\mathrm{C}$ of green hot pepper powder according to drying methods and temperatures

\begin{tabular}{|c|c|c|c|c|c|}
\hline \multirow{2}{*}{ Drying method } & \multirow{2}{*}{$\begin{array}{c}\text { Temp. } \\
\left({ }^{\circ} \mathrm{C}\right)\end{array}$} & \multicolumn{3}{|c|}{ Capsaicinoid $\left(\mathrm{mg} \cdot \mathrm{kg}^{-1}\right)$} & \multirow{2}{*}{$\begin{array}{c}\text { Vit C } \\
\left(\mathrm{mg} \cdot 100 \mathrm{~g}^{-1}\right)\end{array}$} \\
\hline & & Capsaicin & Dihydrocapsaicin & Total & \\
\hline Hypobaric drying & $40^{\circ} \mathrm{C}$ & $749.30 \pm 51.39^{\mathrm{a} 1)}$ & $161.37 \pm 4.09^{\mathrm{a}}$ & $910.67 \pm 49.08^{\mathrm{a}}$ & $209.97 \pm 12.80^{\mathrm{a}}$ \\
\hline Hot-air drying & $50^{\circ} \mathrm{C}$ & $767.73 \pm 36.52^{\mathrm{a}}$ & $172.93 \pm 4.15^{\mathrm{a}}$ & $939.67 \pm 40.39^{\mathrm{a}}$ & $149.87 \pm 6.85^{\mathrm{b}}$ \\
\hline \multicolumn{2}{|c|}{ Significance } & NS & NS & NS & * \\
\hline
\end{tabular}

${ }^{1)} \mathrm{Mean} \pm \mathrm{SE}(\mathrm{n}=3)$ separation within columns by t-test at $\mathrm{p}<0.05$.

NS, ${ }^{*}$ Nonsignificant or significant at $\mathrm{p}<0.05$, respectively.

표피백화를 고려하였을 때 최종 고춧가루의 외관적 품질 은 감압 $35^{\circ} \mathrm{C}$ 와 $40^{\circ} \mathrm{C}$, 열풍 $40^{\circ} \mathrm{C}$ 와 $50^{\circ} \mathrm{C}$ 에서 건조한 제품이 우수하였으며, 건조온도가 낮을수록 수분흡수지수가 높 아 식재료로 이용 시 복원력이 높아지는 것으로 판단되었 다. 각각 건조방법에 따른 건조시간을 고려하였을 때 풋고 추 건조는 감압 $40^{\circ} \mathrm{C}$ 또는 열풍 $50^{\circ} \mathrm{C}$ 로 건조하는 것이 적절한 것으로 판단되었으며, 두 건조방식에서 capsaicinoids는 차이가 없었으나 vitamin $\mathrm{C}$ 함량은 온도가 낮은 감압 $40^{\circ} \mathrm{C}$ 에서 더 높았다.

\section{요 약}

고품질 녹색 고춧가루 생산을 위하여 ‘청양' 품종 (Capsicum. annuum L cv. 'Cheongyang') 풋고추를 송풍형 감압건조와 열풍건조 방식을 이용하여 건조 온도에 따른 건고추 및 고춧가루의 품질을 비교하였다. 송풍형 감압건 조는 $640 \mathrm{mmHg}$ 에서 $35^{\circ} \mathrm{C}, 40^{\circ} \mathrm{C}, 45^{\circ} \mathrm{C}$ 및 $40^{\circ} \mathrm{C}$ 에서 $80 \%$ 이상 건조 후 $45^{\circ} \mathrm{C}$ 에서 건조하였으며, 열풍건조는 $40^{\circ} \mathrm{C}$, $50^{\circ} \mathrm{C}, 60^{\circ} \mathrm{C}$ 및 $50^{\circ} \mathrm{C}$ 에서 $80 \%$ 이상 건조 후 $60^{\circ} \mathrm{C}$ 에서 건조하 였다. 송풍형 감압건조는 열풍건조보다 낮은 온도에서 건 조가 가능했으며, 건조시간을 단축시킬 수 있었다. 외관적 품질은 감압 $35^{\circ} \mathrm{C}, 40^{\circ} \mathrm{C}$, 열풍 $40^{\circ} \mathrm{C}, 50^{\circ} \mathrm{C}$ 에서 건조한 고춧 가루가 우수하였다. 건조시간은 감압 $35^{\circ} \mathrm{C}, 40^{\circ} \mathrm{C}$ 는 각 48 , 31 시간, 열풍 $40^{\circ} \mathrm{C}, 50^{\circ} \mathrm{C}$ 는 각 42,23 시간이 소요되어 경제 성을 고려했을 때 감압 $40^{\circ} \mathrm{C}$ 와 열풍 $50^{\circ} \mathrm{C}$ 가 적절한 것으로 판단되었다. 두 건조방법 모두 건조온도가 높을수록 chlorophyll의 변색이 많이 진행되어 과육갈변이 많이 발생 되었으며, 종자갈변도 많았다. 과피의 표피 조직이 희게 보이는 표피백화는 풋고추 건조에서 나타나는 특이한 증 상으로 건조 온도가 낮아 건조시간이 긴 처리에서 많이 발생되었다. 고춧가루의 녹색도를 나타내는 Hunter a 값은 두 방식 모두 온도가 낮을수록 녹색이 진하게 나타났으나 육안으로는 표피백화로 인해 다소 밝은 녹색을 띄었다. 고춧가루의 수분흡수지수는 건조온도가 낮을수록 높았으 며 수분용해지수는 차이가 없었다. Capsaicinoid는 감압 $40^{\circ} \mathrm{C}$ 와 열풍 $50^{\circ} \mathrm{C}$ 에서 차이가 없었으나, vitamin $\mathrm{C}$ 함량은 온도가 낮은 감압 $40^{\circ} \mathrm{C}$ 에서 더 높았다.

\section{감사의 글}

이 논문은 부산대학교 기본연구지원사업(2년)에 의하 여 연구되었음.

\section{Conflict of interests}

The authors declare no potential conflict of interest.

\section{ORCID}

Hyun-Jin Nam https://orcid.org/0000-0002-4432-3923

Yong-Jae Lee https://orcid.org/0000-0002-1310-1383

\section{References}

Attuquayefio VK, Buckle KA. Rapid sample preparation method for HPLC analysis of capsaicinoids in capsicum fruits and oleoresins. J Agric Food Chem, 35, 777-779 (1987)

Beom HJ, Kang DJ, Lee BD, Shon JH, Im JS, Eun JB. Physicochemical characteristics of powder from hot air and freeze dried leaves and roots of Acorous calamus L. J Korean Soc Food Sci Nutr, 36, 1451-1457 (2007)

Buckle K, Edwards RA. Chlorophyll degradation and lipid oxidation in frozen unblanched peas. J Sci Food Agric, 21, 307-312 (1970)

Butz P, Edenharder R, Garcia AF, Fister H, Merkel C, Tauscher B. Changes in functional properties of vegetables induced by high pressure treatment. Food Res Int, 35, 295-300 (2002)

Cho DM, Moon SH, Kang OG, Jang SM, Lee JW, Lee MH. 
Food Chemistry. Kwangmoonkag, Paju, Korea, p 229-233 (2011)

Choe EO, Lee HG, Park KH, Lee SH. Factors affecting the components of chlorophyll pigment in spinach during storage. J Korean Soc Agric Chem Biotechnol, 44, 73-80 (2001)

Daood HG, Kapitany J, Biacs P, Albrecht K. Drying temperature, endogenous antioxidants and capsaicinoids affect carotenoid stability in paprika (red pepper spice). J Sci Food Agric, 86, 2450-2457 (2006)

Fellows PJ. Food Processing Technology: Principles and Practice. Elsevier, Ed 3. Woodhead Publishing Ltd., Cambridge, UK, p 481-524 (2009)

Hong SH. The future of red pepper powder industry in Korea. Food Ind Nutr, 4, $45-49$ (1999)

Hwang KT, Rhim JW. Effect of various pretreatments and drying methods on the quality of dried vegetables. Korean J Food Sci Technol, 26, 805-813 (1994)

Jeong JW, Seong JM, Park KJ, Lim JH. Quality characteristics of semi-dried red pepper (Capsicum Annuum L.) using hot-air drying. Korean J Food Preserv, 14, 591-597 (2007)

Jin TY, Oh DH, Eun JB. Change of physicochemical characteristics and functional components in the raw materials of Saengsik, uncooked food by drying methods. Korean J Food Sci Technol, 38, 188-196 (2006)

Joo HK, Kim SS, Sa TM. Effect of drying condition on the colors and flavors change of fresh pepper. J Oriental Bot Res, 8, 115-125 (1995)

$\mathrm{Ku} \mathrm{KH}$, Lee KA, Kim YL, Lee YW. Quality characteristics of hot-air dried radish (Raphanus sativus L.) leaves. J Korean Soc Food Sci Nutr, 35, 780-785 (2006)

Kwak YJ, Kim JS. Changes of chlorophyll and SOD-like activities of Chinese chives dehydrated at different heat treatments. J Korean Soc Food Sci Nutr, 38, 879-884 (2009)

Lee SK. Establishment of postharvest technology on quality maintenance in major horticultural crops during storage and distribution. Final Report of MAFRA, maf:9329 (2003)

Lee SK, Kim JK, Park YM, Suh JK, Yang YJ, Hwang YS. Postharvest Handbook: Fruit Vegetable. Kor Ministry of Agr For, Nonghyup, p 31-61 (2006)

Lim YR, Kyung YN, Jeong HS, Kim HY, Hwang IG, Yoo
SM, Lee JS. Effects of drying methods on quality of red pepper powder. J Korean Soc Food Sci Nutr, 41, 1315-1319 (2012)

Lin TM, Durance TD, Scaman CH. Characterization of vacuum microwave, air and freeze dried carrot slices. Food Res Int, 31, 111-117 (1998)

Namgung B, Lee YY, Ha JH. Determination of capsaicinoids in red pepper powder using ultra high performance liquid chromatography. Anal Sci Technol, 26, 256-261 (2013)

Park SH, Koo HJ, Lee HS, Yoo JH, Hwang SY, Sihn EH, Park YH, Lee JH, Cho JS. The physicochemical changes during storage of red pepper powder dried in hot-air by various processing methods. J Korean Soc Food Sci Nutr, 32, 876-881 (2003)

Park SJ, Choi YB, Ko JR, Rha YA, Lee HY. Effects of drying methods on the quality and physiological activities of blueberry (Vaccinium ashei). Culinary Sci and Hospitality Research, 20, 55-64 (2014)

Pyun YR, Kwon YJ, Kim MH, Kim BY, Park JY, Shin HH, Lee DS, Lee SY, Lee JH, Lee HY, Rhim JW, Jeong MS, Choi YH, Hwang JK. Food Process Engineering. Jigu Publishing Co, Paju, Korea, p 413-490 (2014)

Robertson GL. Changes in the chlorophyll and pheophytin concentrations of kiwifruit during processing and storage. Food Chem, 17, 25-32 (1985)

Schoefs B. Chlorophyll and carotenoid analysis in food products. Properties of the pigments and methods of analysis. Trends Food Sci Technol, 13, 361-371 (2002)

Shin KE, Choi SK. Study on the development of short-term green Gochujang using Chengyang green pepper powder and Meju powder. J East Asian Soc Dietary Life, 21, 884-852 (2011)

Siddiqui MW. Postharvest Biology and Technology of Horticultural Crops: Principles and Practices for Quality Maintenance. Aapple Academic Press, Oakville, ON, Canada, p 156-159 (2015)

Yamauchi N, Watada AE. Regulated chlorophyll degradation in spinach leaves during storage. J Am Soc Hortic Sci, 116, 58-62 (1991)

Yang DC. Quality characteristics of Korean hot pepper depending on production area and drying method. MS Thesis, Seoul National University, Korea, p 1-2 (2008) 